\title{
IVABRADINE: A NEW THERAPEUTIC PERSPECTIVE IN CARDIOVASCULAR DISEASE
}

\section{Jiř́i Patočka 1 , Bohumír Plucar ${ }^{2}$}

${ }^{1}$ University of South Bohemia České Budějovice, Faculty of Health and Social Studies, Department of Radiology and Toxicology

${ }^{2}$ Masaryk University Brno, Faculty of Medicine, Institute of Medical Ethics

\begin{abstract}
Summary
Ivabradine is a novel heart-rate-lowering drug that acts specifically on the sinoatrial node by selectively inhibiting the $\mathrm{I}_{\mathrm{f}}$ current, which is the current prevalently responsible for the slow diastolic depolarization of pacemaker cells. Unlike many rate-lowering agents, ivabradine reduces heart rate in a dose-dependent manner both at rest and during exercise without producing any negative inotropic or vasoconstrictor effect. The bradycardic effect of ivabradine is proportional to the resting heart rate, such that the effect tends to plateau. Because ivabradine also binds to hyperpolarization, voltage -gated channels which carry the $\mathrm{I}_{\mathrm{h}}$ current in the eye, transient, dose-dependent changes of the electroretinogram resulting in mild to moderate visual side effects may occur in approximately $15 \%$ of patients exposed to ivabradine. Ivabradine does not cross the cerebrovascular brain barrier and therefore, has no effect on the $I_{h}$ current in central nervous system neurons. ${ }^{1}$ The safety of ivabradine was assessed in a development program that enrolled over 3,500 patients and 800 healthy volunteers in 36 countries from Europe, North and South America, Africa, Asia and Australia, 1,200 of whom being exposed to ivabradine for over 1 year. Ivabradine was associated with a good safety profile during its clinical development and its safety will be furthermore assessed by postmarketing surveillance and during on-going clinical trials. Ivabradine is the first selective and specific $\mathrm{I}_{\mathrm{f}}$ inhibitor, which received marketing authorization in 27 European countries for the symptomatic treatment of chronic stable angina pectoris in patients with normal sinus rhythm who have a contraindication or intolerance of beta-blockers.
\end{abstract}

Key words: angina pectoris - ivabradine - bradycardia - heart rate-lowering agent - f-channel

\section{Souhrn}

Ivabradin je nový lék snižující srdeční frekvenci specifickým účinkem na sinoatriální uzel selektivní inhibicí proudu $\mathrm{I}_{\mathrm{f}}$, který je především zodpovědný za pomalou diastolickou depolarizaci buněk pacemakeru. $\mathrm{Na}$ rozdíl od jiných látek snižujících srdeční frekvenci snižuje ivabradin tepovou frekvenci v závislosti na dávce v klidu i při námaze, aniž by vykazoval negativně inotropní nebo vazokonstrikční efekt. Bradykardický účinek ivabradinu je proporcionální klidové frekvenci, takže jeho efekt přechází v plato. Protože ivabradin se také váže na hyperpolarizační napět'ově řizené kanály, které upravují proud $\mathrm{I}_{\mathrm{h}} \mathrm{v}$ oku, asi u $15 \%$ pacientů se mohou objevit přechodné, na dávce závislé změny elektroretinogramu s mírnými až středními poruchami vidění.

Ivabradin neprochází přes hematoencefalickou bariéru a nemá proto vliv na velikost proudu $\mathrm{I}_{\mathrm{h}} \mathrm{v}$ neuronech CNS. Bezpečnost ivabradinu byla ověřována $\mathrm{v}$ průběhu jeho vývoje na více než 3500 pacientech a 800 zdravých dobrovolnících v 36 zemích Evropy, Severní a Jižní Ameriky, Afriky, Asie a Austrálie. Ivabradin byl podáván 1200 osobám po dobu 1 roku. Během klinického vývoje provedené zkoušky prokázaly jeho bezpečnost stejně jako postmarketingová sledování a klinická pozorování. Ivabradin je prvý selektivní a specifický inhibitor $\mathrm{I}_{\mathrm{f}}$, který se dostal na trh 27 evropských zemí pro symptomatickou léčbu chronické stabilní aginy pectoris u pacientů s normálním sinusovým rytmem, kteř́ mají kontraindikovány beta-blokátory.

Klíčová slova: angina pectoris - ivabradin - bradykardie - látka snižující srdeční frekvenci - f-kanál 


\section{INTRODUCTION}

Alleviation the symptoms of angina and improving the quality of life and functional status are important objectives in the management of patients with chronic stable angina pectoris. A high heart rate induces myocardial ischemia and angina because it both increases oxygen demand and decreases myocardial perfusion. Beta-blockers are effective in reducing anginal symptoms largely by decreasing heart rate. Physicians use beta-blockers, but patient compliance may be limited by the side effects, which include fatigue, depression and sexual dysfunction. Heart rate reduction can also be obtained by the calcium antagonist verapamil and diltiazem and by the new selective heart-rate-reducing agent ivabradine. Ivabradine is a selective and specific $\mathrm{I}_{\mathrm{f}}$ inhibitor that acts on one of the most important ionic currents for the regulation of the pacemaker activity of sinoatrial node cells. Ivabradine has demonstrated dose-dependent anti -ischemic and antianginal effects in a placebocontrolled study. The aim of this short review is to give a brief survey about ivabradine as perspective therapy for stenocardia patients.

\section{HEART RATE-LOWERING AGENTS}

Cardiac pacemaker activity is regulated by at least five different classes of ion channels and by the opposing effects of the sympathetic and parasympathetic stimulation. Inactivation of several genes, including a subunit coding for the potassium channel activated by the muscarinic receptor $\left(\mathrm{I}_{\mathrm{KACh}}\right)$, the calcium channel $\left(\mathrm{I}_{\mathrm{Ca}}\right)$, and the hyperpolarization-activated channel $\left(\mathrm{I}_{\mathrm{f}}\right)$, results in sinus node arrhythmia (Stieber et al., 2004). Pacemaker channels play a major role in the generation of sinoatrial rhythmic activity. However, their expression is not confined to specialized myocardial cells, such as primary and subsidiary pacemakers. Electrophysiological and molecular data collected over the last ten years demonstrated that $\mathrm{f}$-channels are also present in non-pacemaker cardiomyocytes, and become upregulated in cardiac hypertrophy and failure. Mislocalized expression and/or overexpression of f-channels are a consequence of electrophysiological remodelling and, from a clinical point of view, may represent an arrhythmogenic mechanism in heart failure, a condition associated with a high risk of sudden cardiac death. The potential arrhythmogenic role of $I_{\mathrm{f}}$ and the availability of selective f-channel blockers cause $I_{\mathrm{f}}$ to be a suitable therapeutic target in heart disease (Cerbai and Mugelli, 2006).

The $\mathrm{I}_{\mathrm{f}}$ current, first described by Brown et al. in 1979 in pacemaker myocytes, is an inward current that slowly activates on hyperpolarization to the diastolic range of voltages. Next work has amply demonstrated its involvement in the generation of spontaneous activity. The extent of the current activation determines the slope of diastolic depolarization and hence of the pacemaker rate. Since $I_{f}$ is under cyclic adenosine monophosphate (cAMP)-mediated control by beta-adrenergic and muscarinic stimulation, this mechanism underlies neurotransmitter modulation of cardiac rate and is therefore of fundamental physiological relevance. Their key role in pacemaking makes $f$ channels a natural target for drugs aiming at regulation of pacemaker activity and cardiac rate (DiFrancesco, 2005). Several clinical studies demonstrate the importance of the heart rate for the cardiovascular morbidity and mortality. Over the last 50 years, some thought has been given to those substances that selectively reduce the heart rate (Shipke et al., 2006). Both in the past and more recently, rate-reducing drugs that slow pacemaker activity by decreasing the rate of diastolic depolarization have been developed. These drugs act as specific f-channel inhibitors. One of the latest such molecules developed, ivabradine, has a highly specific inhibitory action on f-channels, which atypically depends on the current flow across the channel. These specific properties make the $\mathrm{I}_{\mathrm{f}}$ inhibition by ivabradine a therapeutically beneficial property. Bsed on investigation of the interaction between ratereducing molecules and specific regions of hyperpolarization-activated, cyclic nucleotidegated channels, the molecular components of native f-channels, will provide new strategies for more specific and efficient drug design (Shattock and Camm, 2006).

\section{CHEMISTRY OF IVABRADINE}

Ivabradine (S-16257), IUPAC name 4-[3-[[(8S)3,4-dimethoxy-8-bicyclo[4.2.0]octa-1,3,5-trienyl] methyl-methyl-amino]propyl]-9,10-dimethoxy-4 -azabicyclo[5.4.0] undeca-7,9,11-trien-5-one is tertiary diamine, aromatic derivative of 1,3diaminopropane (Formula I). Compound, which exists in two stereoisomers, was synthesized in 
Laboratoires Servier and recently was patended in USA by Lerestif et al. (2005). Medicinal prod- ucts containing a crystalline form of ivabradine hydrochloride.<smiles>COc1cc2c(cc1OC)CC(=O)N(CCCN(C)C[C@H]1Cc3cc(OC)c(OC)cc31)CC2</smiles>

Chemical structure of ivabradine

\section{PHARMACOLOGY OF IVABRADINE}

Ivabradine is a pure heart rate lowering agent, acting by selective and specific inhibition of the cardiac pacemaker If current that controls the spontaneous diastolic depolarisation in the sinus node and regulates heart rate. The cardiac effects are specific to the sinus node with effects neither on intra-atrial, atrioventricular or intraventricular conduction times, nor on myocardial contractility or ventricular repolarisation. Ivabradine blocks the hyperpolarization-activated cyclic nucleotide-gated channel by gaining access to a binding site within the open channel pore, and are removed from the blocking site by strong hyperpolarization with large inward $\mathrm{I}_{\mathrm{f}}$ through the open channel, analogous to blockade of cardiac pacemaker current by cilobradine and zatebradine as described before now by Van Bogaert and Pittoors (2003).

Comparative effects of ivabradine and propranolol on systemic and cardiac haemodynamics at rest and during exercise showed that for a similar decrease in heart rate at rest and during sympathetic stimulation, acute administration of ivabradine, decreased myocardial oxygen demand to the same extent as a reference betablocker, propranolol, but without evidence of depressant effect on cardiac function (Joannides and al., 2006).

Ivabradine can also interact with the retinal current $\mathrm{I}_{\mathrm{h}}$, which closely resembles cardiac $\mathrm{I}_{\mathrm{f}}$. It participates in the temporal resolution of the visual system, by curtailing the retinal response to bright light stimuli. Under triggering circumstances (e.g. rapid changes in luminosity), partial inhibition of $I_{h}$ by ivabradine underlies the luminous phenomena that may be occasionally experienced by patients. Luminous phenomena (phosphenes) are described as a transient enhanced brightness in a limited area of the visual field (Rosen, 2006).

\section{PHARMACOKINETICS OF IVABRADINE}

Ivabradine is rapidly and almost completely absorbed after oral administration with a peak plasma level reached in about 1 hour under fasting condition. The absolute bioavailability of the film-coated tablets is around $40 \%$, due to first-pass effect in the gut and liver. After oral administrations of ivabradine in doses 10 or 20 $\mathrm{mg}$ (single and repeated) to health volunteers, analysis of pharmacokinetic and pharmacodynamic effect showed that ivabradine exerts a dose-dependent bradycardic effect and that compounds liable for this bradycardic effect is its active $\mathrm{N}$-dealkylated metabolite. It comes to this, that the metabolite is responsible for the initial bradycardic effect, whereas the parent compound is responsible for the duration of action (Ragueneau et al., 1998). The pharmacokinetics of ivabradine and its metabolite were best described by two linked two compartment intravenous bolus and first-order input, with first-pass loss, and first-order output model. When the model was used for simulation it produced an adequate description of both the original data and data arising from a different clinical pharmacology study (DuffulL et al., 2000).

Ivabradine is extensively metabolised by the liver and the gut by oxidation through cytochrome P450 3A4 (CYP3A4) only. The major active metabolite is the $\mathrm{N}$-demethylated derivative 
(S 18982) with an exposure about $40 \%$ of that of the parent compound. The metabolism of this active metabolite also involves CYP3A4. Ivabradine has low affinity for CYP3A4, shows no clinically relevant CYP3A4 induction or inhibition and is therefore unlikely to modify CYP3A4 substrate metabolism or plasma concentrations. Inversely, potent inhibitors and inducers may substantially affect ivabradine plasma concentrations. Ivabradine is eliminated with a main half-life of 2 hours $(70-75 \%$ of the AUC) in plasma and an effective half-life of 11 hours. The total clearance is about $400 \mathrm{ml} /$ min and the renal clearance is about $70 \mathrm{ml} / \mathrm{min}$. Excretion of metabolites occurs to a similar extent via faeces and urine. About $4 \%$ of an oral dose is excreted unchanged in urine.

Pharmacokinetic/Pharnacodynamic relationship analysis has shown that heart rate decreases almost linearly with increasing ivabradine and S 18982 plasma concentrations for doses of up to $15-20 \mathrm{mg}$ twice daily. At higher doses, the decrease in heart rate is no longer proportional to ivabradine plasma concentrations and tends to reach a plateau. High exposures to ivabradine that may occur when ivabradine is given in combination with strong CYP3A4 inhibitors may result in an excessive decrease in heart rate although this risk is reduced with moderate CYP3A4 inhibitors (Camm, 2006).

\section{IVABRADINE IN CLINICAL RESEARCH}

Ivabradine provides an effective and significant, dose-dependent reduction in heart rate, which is also reflected in a reduction in the rate pressure product leading to a reduction in myocardial oxygen consumption. A large clinical program including almost 5000 patients has demonstrated the efficacy and tolerability of ivabradine. The antianginal and anti-ischemic efficacy of Ivabradine was evaluated using a standardized exercise tolerance test in four double-blind randomized trials (two versus placebo, and one each versus the beta-blocker atenolol and the calcium channel blocker amlodipine) involving 3222 patients with chronic stable angina. Ivabradine (5 $\mathrm{mg}$ and $7.5 \mathrm{mg}$ twice daily) was associated with a significant decrease in angina attacks, and the twice-daily dosage regimen provided uniform efficacy over 24 hours. A sustained reduction in heart rate was demonstrated in patients treated for at least one year $(n=713)$ and no rebound effect occurred following the withdrawal of treatment. Moreover, no influence on glucose or lipid metabolism was observed (Steg, 2006).

The recommended starting dose of ivabradine is $5 \mathrm{mg}$ twice daily followed by uptitration to $7.5 \mathrm{mg}$. The new drug will be available as film -coated tablets containing $5 \mathrm{mg}$ and $7.5 \mathrm{mg}$ ivabradine and will be launched over the next few months in European countries.

\section{FUTURE PERSPECTIVES}

Beyond the clinical program in stable angina, different indications for Ivabradine will also be investigated. In this context, the morbidity/ mortality trial BEAUTIFUL has recently been initiated. This large study will include more than 10000 coronary patients with left ventricular dysfunction from 33 different countries. The aim of the study is to demonstrate the prognostic benefits of Ivabradine in this population, with the study results expected in 2008. In addition, the efficacy of Ivabradine in other indications such as heart failure or acute coronary syndrome will also be explored in the future (Tardif, 2006).

\section{REFERENCES}

BARUSCOTTI, M., BUCCHI, A., DiFRANCESCO, D.: Physiology and pharmacology of the cardiac pacemaker ("funny") current. Pharmacol Therap .Vol. 107, p. 59-79, 2005.

BROWN, H., DiFRANCESCO, D., NOBLE, S.: Cardiac pacemaker oscillation and its modulation by autonomic transmitters. J Exp Biol. Vol. 81, p. 175-204, 1979.

CAMM, J.: How does pure heart rate lowering impact on cardiac tolerability? A satelite symposium, World Congress of Cardiology 2006. Barcelona, Spain, September 26. 2006

CERBAI, E., MUGELLI, A.: $\mathrm{I}_{\mathrm{f}}$ in non-pacemaker cells: Role and pharmacological implications. Pharmacol Res. Vol. 53, p. 416.423, 2006.

DiFRANCESCO, D.: Cardiac pacemaker I(f) current and its inhibition by heart rate-reducing agents. Curr Med Res Opin. Vol. 21, p. 1115-1122, 2005.

DUFFULL, S. B. et al.: A pharmacokinetic simulation model for ivabradine in healthy volunteers. Eur J Pharm Sci. Vol. 10, p. 285-294, 2000.

JOANNIDES, R. et al.: Comparative effects of ivabradine, a selective heart rate-lowering agent, and propranolol on systemic and cardiac haemodynamics at rest and during exercise. Br J Clin Pharmacol. Vol. 61, p. 127-137, 2006.

LERESTIF, J.-M. et al.: Process for the synthesis of ivabradine and addition salts thereof with a pharmaceutically acceptable acid. US Patent Application 20050228177, October 13, 2005. 
REGUENEAU, L. et al.: Pharmacokinetic-pharmacodynamic modeling of the effects of ivabradine, a direct sinus node inhibitor, on heart rate in healthy volunteers. Clin Pharmacol Ther. Vol. 64, p. 192-203, 1998

ROSEN, M. R.: If modulation: perspectives in clinical medicine: A satellite symposium, World Congress of Cardiology 2006, Barcelona, Spain, September 2-6. 2006.

SCHIPKE, J. D. et al.: Selective I(f) channel inhibition: an Alternative for treating coronary artery disease? [Article in German] Herz. Vol. 31, p. 55-74, 2006.

SHATTOCK, M., CAMM, A. J.: Pure heart rate reduction: The $\mathrm{I}_{\mathrm{f}}$ channels from discovery to therapeutic target. Br J Cardiol. Vol. 13, p.27-35, 2006.

STEG, P. G: Guidelines for the management of stable angina: place of ivabradine. A satellite symposium, World Congress of Cardiology 2006, Barcelona, Spain , September 2-6. 2006.

STIEBER, J., HOFMANN, F., LUDWIG, A.: Pacemaker channels and sinus node arrhytmia. Trends Cardiovasc Med. Vol. 14, p. 23-28, 2004.

TARDIF, J-C.: From coronary artery disease to heart failure: management with ivabradine. A satelite sympo- sium, World Congress of Cardiology 2006, Barcelona, Spain , September 2-6. 2006

VAN BOGAERT, P. P., PITTOORS, F.: Use-dependent blockade of cardiac pacemaker current $\left(\mathrm{I}_{\mathrm{f}}\right)$ by cilopbradine and zatebradine. Europ J Pharmacol. Vol. 478, p. 161$171,2003$.

\section{Notice:}

1. A similar current, termed $\mathrm{I}_{\mathrm{h}}$, was later described in different types of neurons, where it has a variety of functions and contributes to the control of cell excitability and plasticity. $I_{\mathrm{f}}$ is an inward current activated by both voltage hyperpolarization and intracellular cAMP. In the heart, as well as generating spontaneous activity, $\mathrm{f}$ channels mediate autonomic-dependent modulation of heart rate: $\beta$-adrenergic stimulation accelerates, and vagal stimulation slows, cardiac rate by increasing and decreasing, respectively, the intracellular cAMP concentration and, consequently, the f-channel degree of activation (Baruscotti et al., 2005)

Jiř́ Patočka a Bohumír Plucar prof.patocka@gmail.com 